\title{
Effect of Climate Changes on the Spread of Infectious Disease: A Public Health Threat
}

\author{
Shaheen MNF* \\ Environmental Virology Laboratory, Water Pollution Research Department, \\ Environmental Research Division, National Research Center, Egypt
}

*Corresponding author: Mohamed Shaheen NF, Environmental virology laboratory,

\section{Review Article \\ Volume 5 Issue 1}

Received Date: December 11, 2019

Published Date: January 06, 2020

DOI: $10.23880 /$ oajmb-16000156

Water Pollution Research Department, Environmental Virology Division, National Research Center, Post Code: 12622, Giza, Egypt, Tel: +2 01016710071; E-mail: m_nrc2007@yahoo.com

\section{Abstract}

Infectious diseases can lead to a rapid population declines or species extinctions. Many pathogens of marine taxa and terrestrial are sensitive to humidity, temperature, and rainfall creating synergisms that could impacts biodiversity. Climate warming can lead to increase in the pathogen development and survival rates, disease severity, disease transmission, and host susceptibility. The effects of climate changes on infectious diseases can play a major part in human history, influencing the increase and fall of civilizations and promoting the conquest of new territories. In order to improve our ability to predict wild epidemics, it will be important to separate the independent and interactive impacts of multiple climate drivers on disease effects. In this review, we highlighted the significant climate changes on infectious disease distribution.

Keywords: Biodiversity; Epidemics; Airborne-borne

Abbreviations: WHO: World Health Organization; TBE Tick-Borne Encephalitis.

\section{Introduction}

Emerging infectious diseases and global climate change are two of the greatest environmental challenges in modern times, however there is controversy about the causal relationship between them [1-3]. Climatic conditions often influence disease outbreaks directly [4], and Many experiments and predictive models have shown that climate change and infectious diseases can lead to current and future declines in biodiversity independently
[5,6]. However, Surprisingly, there is little concrete proof that climate-infectious disease interactions cause extensive population decreases [3,7]. Climate change is already in progress and will continue in the coming years, with rising temperatures, changes in global rainfall patterns, a melting of ice and snow and an increasing global average sea level [8]. Several documents by World Health Organization (WHO) showed the impact of global warming on human health [9]. In addition, World Health Organization (WHO) evaluation concluded that it is estimated that the climate change caused an additional 250,000 lives per year from the years 2030 to 2050; 38,000 from direct heat exposure effects for the elderly and 95,000 due to malnutrition for children [10]. 


\section{Open Access Journal of Microbiology \& Biotechnology}

Many studies have documented the impact of climatic changes on the temporal and spatial distribution of infectious illness such as vector-borne, airborne-borne Disease rodent-borne, water-borne and food-borne diseases, including in particular cholera, tick-borne diseases, malaria, and other gastrointestinal diseases. Increases in annual temperatures, rain and the frequency of extreme weather events are projected to have direct and indirect environmental consequences in which pathogens, vectors and host interact [11].

\section{Vector-Borne Disease}

The epidemic of disease vectors, such as sand flies and mosquitoes, is very climate-sensitive and could alter the geographical and seasonal distribution of illnesses. Malaria, dengue, Japanese B encephalitis, and Zika, are among some of the more frequent infectious diseases in Asia and likely to be affected with climate changes [1]. In Europe, several vector-borne diseases have emerged in recent years; these include West Nile fever, vivax malaria, Chikungunya fever, dengue fever, Lyme disease, Leishmaniasis, and tick-borne encephalitis $[12,13]$.Warmer and wetter weather conditions will change previously uninhabitable mosquito regions to favorable breeding grounds that could lead to geographical redistribution of mosquito-borne diseases [11]. Dengue has recorded a 30-fold global incidence over the last 50 years, with around 50 to 100 billion cases worldwide per year and almost half of the population of the world residing in endemic countries with dengue [10]. In addition to the rapid breeding and maturation cycle in hotter and more wetter conditions, Aedes will proliferate quickly as climate change coincides with increasing urbanisation; the increased population density and abundant mosquito breeding areas, such as in household waste which promotes a greater rate of infection [11].

The Aedes albopictus (Asian tiger mosquito) and the Aedes aegipti (yellow fever mosquito) are the main competent vectors for Zika virus, the arboviruses dengue, chikungunya, and yellow fever [14-17]. Ae. albopictus is more adapted to live in temperate climate areas (e.g., Japan, Europe United States, and parts of China) and is more efficient in transmitting of chikungunya virus while Ae. aegypti is recognized as the most efficient urban dengue vector in tropical and subtropical settings $[18,19]$. Flaviviridae virus (such as tick-borne encephalitis, TBE) and bacteria from the genus Borrelia (causing Lyme disease) can be transmitted via Ixodes ticks [20]. In the temperate Northern Hemisphere, Lyme disease is the most prevalent vector-borne disease affecting humans. Rainfall, temperature, and humidity affect the life cycle and habitat of Ixodes ticks, which prefer habitats with relative humidity of at least $85 \%$ and search for hosts when the temperature exceeds approx. $7^{\circ} \mathrm{C}[21]$.

\section{Water-Borne Disease}

The probability of water-borne diseases outbreaks increases, particularly in susceptible nations, due to poor sanitation and clean drinking water shortage. A major outbreak of campylobacteriosis was lately associated with local water contamination in New Zealand following heavy rainfall. This was one of the biggest waterborne diseases in New Zealand, with an estimated 5500 instances, 45 hospital admissions and 3 fatalities, likely for waterborne campylobacteriosis worldwide [22]. Internationally, study is now tackling the links between climate change, changed rainfall patterns, increasing temperatures and the outcome of health [23,24]. Although the impacts of climate change on rainfall are hard to quantify accurately, the climate developments observed are compatible with the predicted consequences. There is a predicted rise in frequency and/or intensity of severe rainfalls [25]. However, the prospective impacts on enteric illnesses of world climate change are still being quantified and the impacts of the rising temperature have not been caused by rainfall. This is mainly due to the heterogeneity, which makes extrapolation to potential future impacts of rainfall effects in distinct environments. The weather and climate factors have lately been investigated in waterborne diseases. A total of 24 researches, primarily from Asia and North America, were recognized between 2001 and 2013 [26]. After a variable lag time, most recent studies found a positive link between increased rainfall or temperature and enteric infection. No important association between rainfall and enteric disease was identified in six researches while two trials have shown beneficial associations with rainfall and rainfall decrease. The authors suggested further studies "examining possible impact modifiers such as the particular type of microorganism, geographical area, season, type of water production, source of water or water treatment" In order to evaluate how to modulate the link between high temperature or heavy rain and waterborne disease [26]. A case-control study was subsequently conducted in Nordic countries to find the incidence of enteric outbreaks substantially linked to extreme rainfall events [27].

In a systematic review conducted to study the link between enteric disease and water treatment parameters 


\section{Open Access Journal of Microbiology \& Biotechnology}

focused on urban regions in developed countries, water supply, river flow, and water temperature were significant risk factors for enteric disease [28]. Moreover, higher temperatures are well known to be linked with the amplification of enteric pathogens, including Vibrio cholera, in the environment [29]. Several studies on enteric viruses in Egypt showed their high frequency in the water environment as well as among the population during winter season [30-34]. Thus, less humid and cooler conditions are suitable for occurrence of these viruses and therefore the incidence of enteric viruses can be reduced by forecasted climate changes.

\section{Airborne-Borne Disease}

The transmission of airborne disease is influenced by environmental factors-both relative humidity and temperature are important. Increasing globalization and urbanization facilitate the transmission of disease to people, thus increasing the opportunity of outbreaks. This means that disease will spread more easily [11]. The atmosphere is transportation medium not only for pollutant particles and gases but also for many biogenic materials of animal and plant origin. Among biogenic materials, virus, molds, plant fibers, bacteria and pollens [8]. The lower temperature was linked with increased respiratory syncytial virus and influenza virus, higher relative humidity was linked with higher respiratory syncytial virus activity when temperature was less than the annual average and was associated with higher influenza virus activity when temperature was greater than annual average. Influenza virus predictors were similar to "humid-rainy" and "cold-dry" for two types of influenza virus peaks [35]. Li et al. [36] revealed that the viral epidemics varied within countries with a wide range of climate patterns. For example, respiratory syncytial virus and influenza virus epidemics occurred earlier in northern Australia than in southern Australia.

A higher level of carbon dioxide in the atmosphere, Rising temperatures, higher humidity, and heavier rainfalls induce faster proliferation of moulds, pollens, and fungi [37]. In addition, high humidity linked with higher temperatures may encourage the growth of house dust mites, cockroaches, and moulds, and, thus, allergen load [38]. Several epidemiological reports have documented a close link between air pollution, global warming, and respiratory allergic diseases, such as bronchial rhinitis and asthma. Climate changes affect the quality, quantity, timing, and distribution of aeroallergens [38]. Also, higher temperatures can induce the migration of biting and stinging insects into new environments, as well as increasing the community of existing insect species [39]. There are also data indicating that air pollution can lead to the asthma development. Therefore, climate change integrated with air pollution may have severe effects on respiratory health, particularly in children [8].

\section{A Prevalent Environmental, Climate-Sensitive Pathogen}

Melioidosis, caused by the bacterium Burkholderia pseudo mallei is endemic to Northern Australia, Southeast Asia, and other tropical areas; accounting for about 89,000 deaths worldwide per year [40]. Pneumonia is the most common etiology but the variation in severity and presentation can make melioidosis difficult to identification, varying from sever fulminant sepsis to chronic non-specific illness. Extreme weather and rainfall conditions indicate a strong link with sever clinical infections [41,42]. B. pseudo mallei are easily isolated from surface water and soil in endemic areas during these extreme weather conditions. The bacterium can be aerosolised and inhaled during heavy rainfall. Moreover, heavy rainfall in the fourteen days prior to presentation is independently linked to more severe diseases and increased deaths. Climate change will likely have a high impact on both the prevalence of melioidosis in current endemic regions and its emergence in new regions [11].

\section{Conclusion}

The impacts of global warming on human health are documented by many official reports, which emphasize the importance risk of climate changes on the rising incidence of many infectious diseases. There is no doubt that climate change will influence the geographical spread of infectious diseases where their incidence and disease severity. Future studies to estimates of the climate change impacts on enteric disease and drinking water quality should attempt to integrate the possible impacts of changes in temperature as well as rainfall. Decisions of public health and necessary adaptive policies require proactive implementation. Accurate predictions and surveillance on the effects of climate change on infectious diseases are of critical issue.

\section{References}

1. Harvell CD, Mitchell CE, Ward JR, Altizer S, Dobson $\mathrm{AP}$, et al. (2002) Ecology-Climate warming and disease risks for terrestrial and marine biota. Science 296(5576): 2158-2162. 


\section{Open Access Journal of Microbiology \& Biotechnology}

2. Lafferty KD (2009) The ecology of climate change and infectious diseases. Ecology 90(4): 888-900.

3. Rohr JR, Dobson AP, Johnson PT, Kilpatrick AM, Paull SH, et al. (2011) Frontiers in climate change-disease research. Trends Ecol Evol 26(6): 270-277.

4. Pascual M, Chaves L, Cash B, Rodó X, Yunus M (2008) Predicting endemic cholera: The role of climate variability and disease dynamics. Climate Research 36: 131-140.

5. Liu X, Rohr JR, Li Y (2013) Climate, vegetation, introduced hosts and trade shape a global wildlife pandemic. Proceedings of the Royal Society Proc Biol Sci 280(1753): 20122506.

6. Patz JA, Campbell-Lendrum D, Holloway T, Foley JA (2005) Impact of regional climate change on human health. Nature 438(7066): 310-317.

7. Cahill AE, Aiello-Lammens ME, Fisher-Reid MC, Hua X, Karanewsky CJ (2013) How does climate change cause extinction? Proceedings of the Royal Society B-Biological Sciences 280(1750): 2012.1890.

8. Patella V, Florio G, Magliacane D, Giuliano A, Crivellaro MA, et al. (2018) Urban air pollution and climate change:"The Decalogue: Allergy Safe Tree" for allergic and respiratory diseases care. Clin Mol Allergy 16: 20.

9. WHO (World Health Organization) (2005) Air quality guidelines for particulate matter, ozone, nitrogen dioxide and sulphur dioxide. Global Update. In summary of risk assessment. http://apps.who.int/iris/bitstream/handl e/10665 /69477 /WHO_SDE_PHE_OEH_06.02_eng.pdf;jsess ionid $=21948$ A7B88 EA2D5 BFB55 A5F84 629FF 39 seq uence $=1$.

10. WHO (World Health Organization). Climate Change and Health. Available at: http://www.who.int/en/news-room/factsheets/detail/climate-change-and-health. Accessed on 18 July 2018.

11. Dennis S, Fisher D (2018) Climate Change and Infectious Diseases: The Next 50 Years. Ann Acad Med Singapore 47(10): 401-404.
12. Baylis M (2017) Potential impact of climate change on emerging vector-borne and other infections in the UK. Environ Health 16(1): 112.

13. Semenza JC, Suk JE (2018) Vector-borne diseases and climate change: a European perspective. FEMS Microbiol Lett 365(2): 244.

14. Bonica MB, Goenaga S, Martin ML, Feroci M, Luppo V, et al. (2019) Vector competence of Aedes aegypti for different strains of Zika virus in Argentina. PLoS Negl trop dis 13(6): e0007433.

15. Carrington LB, Tran BCN, Le NTH, Luong TTH, Nguyen TT et al. (2018) Field-and clinically derived estimates of Wolbachia-mediated blocking of dengue virus transmission potential in Aedes aegypti mosquitoes. Proc Natl Acad Sci USA 115(2): 361-366.

16. Magalhaes T, Robison A, Young MC, Black WC 4th , Foy B, et al. (2018) Sequential infection of Aedes aegypti mosquitoes with chikungunya virus and Zika virus enhances early Zika virus transmission. Insects 9: 177.

17. Leta S, Beyene TJ, De Clercq EM, Amenu K, Kraemer MUG et al. (2018) Global risk mapping for major diseases transmitted by Aedes aegypti and Aedes albopictus. Int J Infect Dis 67: 25-35.

18. Gould EA, Higgs S (2009) Impact of climate change and other factors on emerging arbovirus diseases. Trans R Soc Trop Med Hyg 103(2): 109-121.

19. Messina JP, Brady OJ, Pigott DM, Golding N, Kraemer MU et al. (2015) The many projected futures of dengue. Nat Rev Microbiol 13(4): 230-239.

20. Caminade C, McIntyre KM Jones AE (2019) Impact of recent and future climate change on vector-borne diseases. Ann N Y Acad Sci 1436(1):157-173.

21. Süss J, Klaus C, Gerstengarbe FW, Werner PC (2008) What makes ticks tick? Climate change, ticks, and tick-borne diseases. J Travel med 15(1): 39-45.

22. NZ Government. Government Inquiry into Havelock North Drinking Water. Wellington; 2017.

23. Ebi K, Ogden NH, Semenza JC, Woodward A (2017) Detecting and attributing health burdens to climate change. Environ Health Perspect 125(8): 085004. 


\section{Open Access Journal of Microbiology \& Biotechnology}

24. Levy K, Smith SM, Carlton EJ (2018) Climate change impacts on waterborne diseases: moving toward designing interventions. Curr Environ Health Rep 5(2): 272-282.

25. Barros VR, Field CB, Dokken DJ, Mastrandrea MD, Mach KJ, et al. (2014) Climate Change impacts, adaptation, and vulnerability. Contribution of Working Group II to the Fifth Assessment Report of the Intergovernmental Panel on Climate Change. Cambridge, UK: Cambridge University Press 2014.

26. Guzman Herrador BR, De Blasio BF, MacDonald E, Nichols G, Sudre B, et al. (2015) Analytical studies assessing the association between extreme precipitation or temperature and drinking waterrelated waterborne infections: a review. Environ Health 14: 29.

27. Guzman Herrador B, De Blasio BF, Carlander A, Ethelberg S, Hygen HO, et al. (2016) Association between heavy precipitation events and waterborne outbreaks in four Nordic countries, 1992-2012. J water health 14(6): 1019-1027.

28. Beaudeau P (2018) systematic review of the time series studies addressing the endemic risk of acute gastroenteritis according to drinking water operation conditions in urban areas of developed countries. Int J Environ Res Public Health 15(5): E867.

29. Lipp EK, Huq A, Colwell RR (2002) Effects of global climate on infectious disease: the cholera model. Clin Microbiol Rev 15(4): 757-770.

30. Shaheen MN, Elmahdy EM (2019) Environmental monitoring of astrovirus and norovirus in the Rosetta branch of the River Nile and the El-Rahawy drain, Egypt. Water Supply 19(5): 1381-1387.

31. Shaheen MNF (2018) Burden of Adenovirus, Astrovirus, Norovirus and Rotavirus Gastroenteritis in Egyptian Children during 2000-2017. J med Microb Diagn 7(3): 283.

32. Shaheen MNF, Elmahdy EM (2019) Molecular Detection of Group C Rotavirus in Environmental Samples in Giza, Egypt. Asian Journal of Water, Environment and Pollution 16 (4):17-22.
33. Shaheen MN, Abd El-Daim SE, Ahmed NI, Elmahdy EM (2019) Environmental monitoring of Aichi virus and human bocavirus in samples from wastewater treatment plant, drain, and river Nile in Egypt. Journal of Water and Health.

34. Shaheen MN, Abd El-Daim SE, Ahmed NI, Elmahdy EM (2018) Molecular detection of three gastroenteritis viruses in in urban sewage treatment plant and river water in Egypt. Egyptian Journal of Aquatic Biology and Fisheries 22(5): 615-627.

35. Tamerius JD, Shaman J, Alonso WJ, Bloom-Feshbach K, Uejio CK, et al. (2013) Environmental predictors of seasonal influenza epidemics across temperate and tropical climates. PLoS pathogens, 9(3): e1003194.

36. Li Y, Reeves RM, Wang X, Bassat Q, Brooks WA (2019) et al. Global patterns in monthly activity of influenza virus, respiratory syncytial virus, parainfluenza virus, and metapneumovirus: a systematic analysis. Lancet Glob Health 7(8): e1031-e1045.

37. Chan AW, Hon KL, Leung TF, Ho MH, Rosa Duque JS, et al. (2018) The effects of global warming on allergic diseases. Hong Kong Med J 24(3): 277-284.

38. D'Amato G, Rottem M, Dahl R, Blaiss M, Ridolo E, et al.(2011) WAO Special Committee on Climate Change and Allergy. Climate change, migration, and allergic respiratory diseases: an update for the allergist. World Allergy Organ J 4(7):120-125.

39. D’Amato G, Annesi-Maesano I, Vaghi, A, Cecchi L, D'Amato M (2018) How do storms affect asthma? Curr Allergy Asthma Rep 18(4): 24.

40. Wiersinga WJ, Virk HS, Torres AG, Currie BJ, Peacock SJ, et al. (2018) Melioidosis. Nat Rev Dis Primers 4: 17107.

41. Currie BJ, Fisher DA, Howard DM, Burrow JN, Lo D, et al. (2000) Endemic melioidosis in tropical northern Australia: a 10-year prospective study and review of the literature. Clin Infect Dis 31(4): 981-986.

42. Currie BJ, Jacups SP (2003) Intensity of rainfall and severity of melioidosis, Australia. Emerg Infect Dis 9(12): 1538-1542. 